\title{
INFLUENCE OF SELECTIVE LIGHT ON RHYSOGENESIS IN SEEDLING OF PLANTS CONTRASTED BY PHOTOPERIODIC REACTION
}

\author{
Avksentieva O. O., Batuyeva Ye. D.
}

\section{INTRODUCTION}

A well-developed root system is necessary for the full use of soil resources by the plant and, therefore, to ensure high yields. Since the root system of plants is the result of branching of the main and additional roots, to understand the processes of root system formation and regulation, it is necessary to clarify the basic processes underlying the initiation and development of lateral roots, i.e. rhizogenesis.

The roots of plant seedlings are an extremely convenient model object for studying the processes of morphogenesis. It grows rapidly, has a relatively simple anatomical structure and a fairly well-defined meristem. Some features of root morphogenesis, especially those are at the cellular level, are common to the plant as a whole and, thus, can be extrapolated to other organs. The formation of lateral roots, along with purely genetic factors are influenced by various external and internal factors, such as positional control factors, hormonal regulation, environmental influences, including exposure to light of different spectra ${ }^{1}$.

The problem of studying the mechanisms of regulation of plant photomorphogenesis is relevant in modern phytophysiology. One of the most important factors in the regulation of growth and development - the morphogenesis of plants is light, the action of which becomes apparent through the activation of specific photoreceptors. Plants perceive the light signal through five photoreceptor systems: phytochromes, cryptochromes, phototropins, F-box proteins, UV-B light receptors ${ }^{2}$.

The main photoreceptor complex of plants is a system of phytochromes sensors of red (RL) and far-red (FRL) light ${ }^{3}$. Nowadays, the

${ }^{1}$ Молекулярно-генетические и гормональные механизмы ветвления корневых систем / Е.Л. Ильина и др. Сельскохозяйственная биология. 2017. Т. 52. № 5. C. 856-868. DOI: 10.15389/agrobiology.2017.5.856rus.

2 Войцеховская О.В. Фитохромы и другие (фото)рецепторы информации у растений. Физиология растений. 2019. Т. 66. № 3. С. 163-177. DOI: 10.1134/S0015330319030151.

3 Головацкая И.Ф. Морфогенез растений и его регуляция : учебное пособие. Томск : ТГУ, 2016. $171 \mathrm{c.}$ 
physicochemical properties of phytochromes have been studied in detail ${ }^{4}$, the structures of molecules and mechanisms of their photoconversion, different forms of phytochromes - Phy A- $\mathrm{E}^{5}$, their localization in the cell, biosynthesis and genetic control of formation ${ }^{6}$, the main molecular mechanisms of phytochrome signal transduction and its integration with phytohormonal and stress signaling? ${ }^{7}$.

The phytochrome system controls almost the whole individual development of plants - from seed germination to flowering and fruiting. It is established that the activity of phytochromes affects not only the growth of the overground part of the plant, but also the growth of roots. This is due to both the activation of root phytochromes and the transduction of signaling from the overground part to the roots ${ }^{8}$.

It is known that phytochromes are localized in almost all plant tissues, including seedlings, leaves of monocotyledonous and dicotyledonous plants, roots, cotyledons, fruits, seeds, and others. However, different plant organs have been shown to concentrate different forms of phytochromes. The maximum content of phytochrome A - the most unstable form - is characterized by meristem cells of etiolated seedlings, in the green organs of plants and organs that grow under intense light - the main is phytochrome $\mathrm{B}^{9}$. The variety (sometimes the opposite) of the effects of phytochrome signaling is appears in plants of different systematic groups - monocotyledonous and dicotyledonous; plants that grow under different lighting conditions - shade-loving and lightloving; plants with different seed structure - small-seeded and large-seeded (with a large supply of nutrients).

Photoperiodic signal transduction in the plant organism is also carried out with the participation of phytochromes, which coordinate the circadian

${ }^{4}$ Синещеков В.А. Фитохром А: полиморфизм и функциональность. Москва : Научный мир, 2013. 162 с.

${ }^{5}$ Franklin K.A., Quail P.H. Phytochrome functions in Arabidopsis Development. J. Exp. Botany. 2010. V. 61. P. 11-24. DOI: 10.1093/jxb/erp304..

Федоренко О.М., Савушкин А.И. Генетические аспекты фитохромной регуляции процессов фотоморфогенеза у высших растений. Успехи современной биологии. 2006. Т. 126. № 2. С. 201-212.

${ }^{7}$ Franklin K.A., Whitelam G.C. The signal transducing photoreceptors of plants. Int. J. Dev. Biol. 2005. V. 49. P. 653-664. DOI: 10.1387/ijdb.051989kf.

${ }^{8}$ Root-localized phytochrome chromophore synthesis is required for photoregulation of root elongation and impacts root sensitivity to jasmonic acid in Arabidopsis / S.E. Costigan et al. Plant Physiol. 2011. V. 157. P. 1138-1150. DOI: 10.1104 / стр.111.184689.

9 Кулаева О.Н. Как свет регулирует жизнь растений. Соросовский образовательный журнал. 2001. № 7. С. 6-12. 
rhythm of processes in the plant and regulate the transition to flowering ${ }^{10}$. Most studies of phytochromic effects have been performed mainly on the model object Arabidopsis thaliana or on other plants without taking into account their photoperiodic reaction, which does not allow to draw conclusions about the role of photoperiodic reaction of plants in the effects of RL on photomorphogenesis.

Among all parts of the spectrum in photomorphogenetic reactions, the least studied is the green light (GL 500-600 nm). Green light is a factor that regulates the morphology of cells, tissues and organs, the processes of photosynthesis, respiration and growth, the duration of the stages of ontogeny of plants. According to modern notions, a large number of different compounds are considered as receptors of the GL: rhodopsins, cytochromes, carotenoids, heliochromes, cryptochromes and phytochromes, allantoins, and others, or still unknown photoreceptor compounds ${ }^{11}$. Green light is involved in the regulation of endogenous levels of phytohormones, supporting the synthesis and redistribution of auxin, increasing the expression of genes activated by auxins, gibberellins and brassinosteroids and in the breakdown of DELLA proteins. Photoreactions on the GL are usually low-energy. The ability to absorb the GL allows plants to more fully assess the light conditions and adequately respond to their changes in the phytocenosis during the day or season. It is not accidentally that the mechanisms of stomatal movement, seed germination and circadian rhythms are controlled by the ratio of green / blue (GL / BL) light. GL is especially important in the early stages of plant ontogenesis, because the correct assessment of light conditions allows to include an adequate development program to regulate the size and morphological structure of the seedling ${ }^{12}$.

Blue light $(\mathrm{BL})$ is a significant factor that regulates photomorphogenesis of plants. In Arabidopsis, 4 major photoreceptors of blue light were identified: two cryptochromes (Cry1 and Cry2) and two phototropins (Phot1 and Phot 2$)^{13}$. Blue light with the help of cryptochromes and phototropins regulates the movement of chloroplasts in higher plants, inhibition of

${ }^{10}$ Генетична детермінація та функція RR-білків - регуляторів фотоперіодичних реакцій і циркадних ритмів у рослин / В.М. Тоцький та ін. Цитология и генетика. 2012. T. 46. № 5. C. 72-91. DOI: 10.3103/S009545271205009X.

11 Головацкая И.Ф., Карначук Р.А. Роль зеленого света в жизнедеятельности растений. Физиология растений. 2015. Т. 62. № 6. С. 776-791. DOI: $10.7868 / 80015330315060081$.

${ }^{12}$ Casal J.J. Photoreceptor signaling networks in plant response to shade Annu. Rev. Plant Biol. 2013. V. 64. P. 403-427. DOI: 10.1146/annurev-arplant-050312-120221.

${ }^{13}$ Plant flavoprotein photoreceptors / J.M. Christie et al. Plant Cell Physiol. 2015 Mar;56(3):401-13. DOI: 10.1093/pcp/pcu196. 
hypocotyl elongation, circadian rhythms, phototropism, opening of stomata, synthesis of anthocyanins etc.

The integration of photoreceptors allows the plant to obtain information about the intensity of light, its spectral composition, the length of daylight, as well as the ambient temperature, the presence of pathogens, competing neighbors and other information ${ }^{14}$. Due to this, the plant synchronizes environmental factors with internal physiological and biochemical processes, which leads to changes in the course of growth and development.

Despite the huge amount of accumulated data on the influence of various factors on the morphogenesis of the root system, the role of the influence of selective light on the processes of rhizogenesis is still poorly understood. Therefore, based on the above, the aim of this work was to study the effect of selective light of different spectrum of RL $(660 \mathrm{~nm})$, GL $(530 \mathrm{~nm}), \mathrm{BL}$ $(450 \mathrm{~nm})$ on the processes of rhizogenesis in plants with contrast photoperiodic reaction.

Materials and methods. As a plant material in the work we used members of the legume family (Fabaceae), contrasting by photoperiodic reaction (PhPR). The photoperiodic reaction of plants is an important adaptive feature of plants, which determines the regulation of physiological processes and the transition from vegetative to generative development. Photoperiodic sensitivity is a genetically determined trait. Nowadays, genetic systems that regulate the photoperiodic sensitivity of the long-day plant (LDP) of pea and short-day plant (SDP) of soybeans are known ${ }^{15}$. Photoperiodic signal and its synchronization with circadian rhythmics are carried out by means of photoreceptor systems ${ }^{16}$.

Long-day pea (Pisum sativum L.) plants of the Metsenat variety, shortday plants of soybean (Glycine $\max$ (Merr.) L.) of the Korsak variety and photoperiodically neutral soybean plants of the cultivar of Didema Podillia were used. The studied varieties are included in the State Register of Plant Varieties of Ukraine. Seeds for research were provided by the staff of The Plant Production Institute nd. a. V. Ya. Yuryev of NAAS.

The seeds of the experimental plants were gradually sterilized in $15 \%$ sodium hypochlorite solution (15 minutes) and 70\% ethanol (1 minute) and germinated on moistened filter paper in a thermostat at $24^{\circ} \mathrm{C}$ for 2 days. Activation of photoreceptor systems was performed according to a

${ }^{14}$ Light-regulation plant growth and development / C. Kami et al. Curr. Top. Dev. Biol. 2010. V. 91. P. 29-66. DOI: 10.1016/S0070-2153(10)91002-8.

${ }^{15}$ Weller J.L., Ortega R. Genetic control of flowering time in legumes Front. Plant Sci., 2015. DOI: https://doi.org/10.3389/fpls.2015.00207.

${ }^{16}$ Molecular Dissection of the Roles of Phytochrome in Photoperiodic Flowering in Rice / A. Osugi et al. Plant Physiology. 2011. V. 157. P. 1128-1137. DOI: https://doi.org/10.1104/pp.111.181792. 
previously developed protocol, irradiating the test plants for 30 minutes with monochromatic red $(660 \mathrm{~nm})$, green $(530 \mathrm{~nm})$ and blue $(450 \mathrm{~nm})$ light using LED matrices for 3 days. Control plants were cultured under the same conditions, but without photoreceptor activation by selective light.

The growth reaction was analyzed according to the indicators of linear growth, morphometric parameters of the root system were determined: the length of the main and lateral roots; integrated indicator of growth and biosynthetic processes - raw biomass of the root system; indicators of rhizogenesis - the number and length of lateral roots. Measurements were performed at the end of the experiment on the 5th day so that the effects of activation of phytochromes had time to appear, analyzing in each variant of 10-15 seedlings.

Also performed microscopic analysis - areas of root hairs (rhizoderm) using a light microscope Micromed XS-2610 at a magnification of $\times 40$. We prepared temporary micropreparations separating the suction area from the main root with a scalpel and placing it on a glass slide in a drop of water the so-called "pressed" drug. The micropreparations were photographed with a Lenovo A536 camera and the area of the root hairs (rhizoderm) was calculated using PhotoM 1.21.

Statistical analysis was performed using the software package OpenOffice and Statistica 5.0. The tables and graphs show the average values and their standard errors. The significance of differences between control and experimental variants was determined using Student's t-test at $p \leq 0.05$.

\section{The effect of selective light on the growth of the seedlings root system}

The root is the vegetative organ of the plant, which fixes the plant organism in the soil and provides its mineral nutrition to the plant. In the structure of the root there are the main zones: the zone of cell division (meristem), the zone of elongation, the zone of root hairs (maturation), the zone of conduction (transport of substances). Root growth is provided by the activity of the root apical meristem (RAM), which is located in the apex of the root and covered with a root cap. RAM is represented by cells of the socalled rest center (RC) and cells with initials that are able to constantly proliferate - stem cells of the plant organism. As a result of their division, rows of cells (so-called cell files) are formed, which form the main tissues of the root: epidermis (rhizoderm), conductive (transport) tissues and the primary cortex - the cortex ${ }^{17}$.

The growth of roots in length is ensured by the activity of exactly two zones - the meristem, where cells divide directly, and the zone of elongation, where

17 Эверт В.Ф. Анатомия растений Эзау. Меристемы, клетки и ткани растений: строение, функции и развитие. Москва : БИНОМ, 2016. 600 с. 
cells grow intensively, carrying out a specific growth "stretching", characteristic of the plant organism. Despite the large size of the root system of plants, root growth is carried out in the growth zone, which does not exceed one centimeter. Mitosis - cell divisions are concentrated only in the apical meristematic zone the zone of proliferative activity ${ }^{18}$.

Auxin plays a key role in the development of the root system at all stages, from the moment the root is laid in embryogenesis. Auxin determines the position and formation of the niche of stem cells in the meristem of the root, regulates the mitotic activity of RAM and the development of lateral roots. The distribution of auxin in root tissues plays an important role in the development of the root system of the plant organism. The direction of polar transport provided by membrane carrier proteins - PIN, positional signaling, auxin concentration distribution on root tissues - are all important regulatory factors that control the formation, growth and development of the root system of the plant organism ${ }^{19}$.

The growth reaction is an integral indicator of the manifestation of the program of plant morphogenesis. The results of the study of the influence of selective light irradiation of different spectrum of RL $(660 \mathrm{~nm})$, GL $(530 \mathrm{~nm})$ and BL $(450 \mathrm{~nm})$ on the morphogenesis of the root system of pea LDP variety Metsenat, SDP soybean Korsak and PNP soybean Diadema Podillia showed by photoperiodic reaction (Table 1).

When irradiated with selective light of different spectra of plants of the LDP of the pea variety Metsenat, it is shown (Table 1) that the length of the main root increased significantly only under the action of green light (530 $\mathrm{nm})$. Irradiation of the RL slightly inhibited the growth of the main root in length, irradiation of the $\mathrm{BL}$ - did not affect the growth response of the main root. The biomass of the roots of the LDP of the pea variety Metsenat under the influence of the RL and the GL increased significantly, the irradiation of the BL led to an insignificant decrease in the accumulation of root biomass. The biomass/length index, which characterizes the accumulation of biomass per unit length of root, increases with irradiation of the RL and the GL and decreases slightly with the irradiation of the BL.

${ }^{18}$ Иванов В.Б. Клеточные механизмы роста растений. Москва : Наука, 2011. 104 с.

19 Alarcón M. Victoria, Salguero Julio and Lloret Pedro G. Auxin Modulated Initiation of Lateral Roots Is Linked to Pericycle Cell Length in Maize Front. Plant Sci. 2019. URL: https://doi.org/10.3389/fpls.2019.00011. 
Table 1

Influence of selective light on the growth reaction of the root system in seedlings with contrast photoperiodic reaction

\begin{tabular}{|c|c|c|c|}
\hline Variant & Length, $\mathrm{cm}$ & Mass, $\mathrm{mg}$ & Mass / length \\
\hline \multicolumn{4}{|c|}{ Long-day plant $(\mathrm{LDP})$ of pea Metsenat variety } \\
\hline Control & $11,04 \pm 0,47$ & $280,0 \pm 10,3$ & 25,36 \\
\hline RL $(660 \mathrm{~nm})$ & $10,83 \pm 0,46$ & $309,6 \pm 3,6^{*}$ & $28,59^{*}$ \\
\hline GL $(530 \mathrm{~nm})$ & $13,11 \pm 0,37^{*}$ & $376,6 \pm 2,8^{*}$ & $28,73^{*}$ \\
\hline BL $(450 \mathrm{~nm})$ & $11,03 \pm 0,58$ & $268,3 \pm 10,7$ & 24,32 \\
\hline \multicolumn{4}{|c|}{ Short-day plant $($ SDP) of soybean Korsak variety } \\
\hline Control & $6,10 \pm 0,21$ & $123,1 \pm 12,1$ & 20,18 \\
\hline RL $(660 \mathrm{~nm})$ & $4,72 \pm 0,64^{*}$ & $139,1 \pm 8,5^{*}$ & $29,60^{*}$ \\
\hline GL $(530 \mathrm{~nm})$ & $1,83 \pm 0,50^{*}$ & $120,6 \pm 9,8$ & $67,00^{*}$ \\
\hline BL $(450 \mathrm{~nm})$ & $2,91 \pm 0,91^{*}$ & $128,6 \pm 31,1$ & $44,34^{*}$ \\
\hline Photoperiodically neutral plant $($ PhNP) of soybean Diadema Podillia variety \\
\hline Control & $5,62 \pm 0,33$ & $198,6 \pm 10,3$ & 35,46 \\
\hline RL $(660 \mathrm{~nm})$ & $5,54 \pm 1,50$ & $211,1 \pm 13,1^{*}$ & 38,38 \\
\hline GL $(530 \mathrm{~nm})$ & $4,83 \pm 0,45^{*}$ & $191,0 \pm 6,2^{*}$ & 39,79 \\
\hline BL $(450 \mathrm{~nm})$ & $3,25 \pm 0,96^{*}$ & $200,8 \pm 15,0$ & $62,75^{*}$ \\
\hline
\end{tabular}

*) note - the difference with the control is significant for $p \leq 0,05$

Thus, the results of experiments show that the root system of LDP of pea varieties Metsenat stimulates growth by irradiation of the GL, the accumulation of biomass - by the action of the GL and RL, irradiation of the $\mathrm{BL}$ does not affect the studied processes.

The results of the study of the influence of selective light on the growth and accumulation of biomass of SDP plants Korsak variety and PhNP of Diadema Podillia variety showed that the experimental SDP and PhNP were characterized by almost twice lower linear growth and biomass accumulation compared to LDP seedlings. In SDP seedlings of Korsak soybean, the growth reaction of the main root was inhibited by selective light irradiation, especially significantly - almost three times under the action of the GL (Table 1). At the same time, the accumulation of biomass by the root system under the influence of the RL and BL does not change. Irradiation of the RL leads to the stimulation of biosynthetic processes and a significant increase in root biomass. Inhibition of linear growth and biomass accumulation probably indicates inhibition of growth of "stretching" of the main root, which is determined by auxin, and stimulation of rhizogenesis branching of roots in seedlings of SDP soybeans. The biomass/length index of soybean SDP seedlings is significantly increased by selective light irradiation due to significant inhibition of linear growth of the main root. The results of the study of the influence of selective light on the linear growth of the main root in PNP soybean cultivar Diadema Podillia showed that under the action of the RL changes in growth do not occur, irradiation of 
the GL and BL significantly inhibits the growth response (Table 1). The accumulation of biomass under irradiation of the RL is stimulated, under the action of the GL - on the contrary decreases, and under the influence of the BL - does not change significantly. The biomass/length index increases significantly only in seedlings irradiated with BL due to significant inhibition of linear growth of the main root (Table 1).

Thus, under the influence of selective light on soybean seedlings, cultural changes in the growth reaction of roots occur in the same direction, but in the Korsak cultivar these changes are more pronounced than in $\mathrm{PhPN}$ seedlings of the Diadema Podillia.

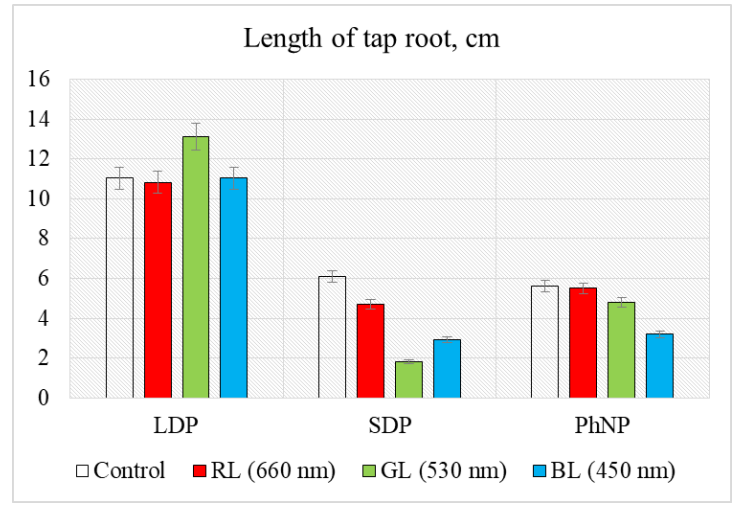

Fig. 1. The effect of selective light on the length of the main root in seedlings with contrast PhPR

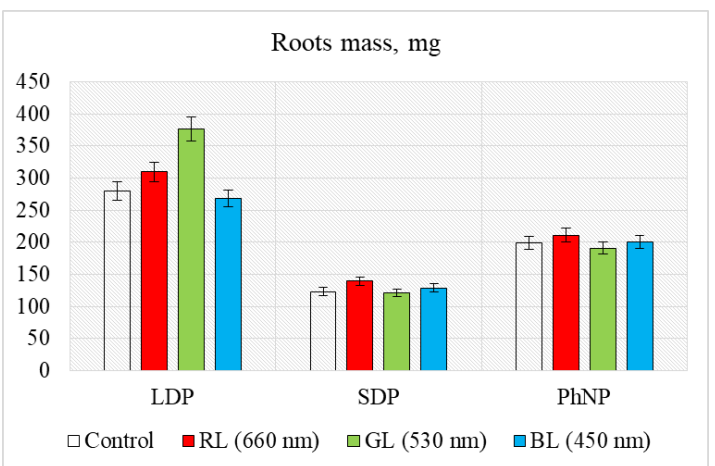

Fig. 2. Influence of selective light on root mass in seedlings with contrast PhPR 
Thus, the opposite manifestation of the growth reaction in plants with contrast photoperiodic reaction was detected only by irradiation of the GL: in the LDP irradiation of the GL leads to stimulation of linear growth and accumulation of root biomass, in SDP - to inhibition of linear growth of the main root, in $\mathrm{PhNP}$ - to inhibition of growth and accumulation of root biomass (Fig. 1,2). Under the influence of the RL is the stimulation of biomass accumulation by roots in plants with contrast PhPR. BL irradiation inhibits linear growth in SDP and PhNP of plants and does not affect changes in root biomass in plants with contrast PhNP.

\section{The influence of selective light on the development of lateral roots (rhizogenesis)}

The most important function of the root of the plant organism is providing mineral nutrition in a heterogeneous environment with an uneven distribution of nutrients. The need to compensate for this unevenness leads to branching of the root and the formation of the root system.

Due to the branching of the roots, the structure of the root system is formed, which determines the possibility of increasing the area of contact of plants with the substrate and their adaptability to obtain water from substrates of different types. The initiation of the lateral root in seed plants is the result of the restoration of proliferation in differentiated cells of the pericycle, as a result of which the apical meristem of a new organ is formed. In most plants, the lateral roots are laid in the pericycle in the leading zone. This is of great biological importance to plants. With the formation of root rudiments on the roots there are bumps. Laying of lateral roots in the leading zone does not interfere with the process of absorption and radial transport of substances. Endogenous branching of roots protects their rudiments in the initial stages of development from damage in contact with the soil. The formation of lateral roots in the pericycle has certain localization. More often lateral roots are differentiated in a pericycle against rays of a xylem, and at some plants (cereals, celery) - against rays of a phloem. In both cases, the plants have as many rows of lateral roots as the rays of the xylem (or phloem) in the radial conducting bundle. The process begins with the division of several cells of the pericycle, first perpendicular and then parallel to the surface, which leads to a small tubercle. In the beginning the cone of growth of the future lateral root is formed. At the same time, the cells of the endoderm, which are adjacent to the emerging rudiment, and sometimes the nearest layers of the cortical parenchyma, divide. From them a pocket is formed, which helps the embryonic root to break through the rather powerful primary bark of the main root. The pocket acts not only mechanically, pushing the cells of the cortex, but also affects them with enzymes that break 
down cell membranes and thus facilitate the movement of the lateral $\operatorname{root}^{20}$. Currently, a huge amount of factual material has been accumulated, covering many aspects of lateral root morphogenesis. Significance was shown for the initiation of the lateral root of the cell cycle phase and the sequence of cell generations in the meristem, which determine the possibility of its positional control. On the example of Arabidopsis thaliana L. identified classes of genes, the sequential expression of which leads to morphogenetic processes that lead to the development of a new root.

The phytohormone auxin performs multiple functions at the initiation of the lateral root. It participates in the initial stages of formation of the competence of pericycle cells to the first divisions, in the formation of primordia, and also ensures its successful advancement of the lateral root through the cortex of the maternal root. Key factors involved in the formation of local competence of pericycle cells to initiate lateral root primordia are GATA23 transcription factor and membrane-associated kinase-type regulator MAKR $4^{21}$. Particular attention is paid to the role of root tissues surrounding the pericycle in the regulation of the initial stages of cell proliferation during the initiation of the lateral root. The root system of legumes - in our experiments of pea variety Maecenat and soybean varieties Korsak and Diadema Podillia by type of structure of the rod, i.e. there is a well-developed main root and lateral roots. Branching of the root system - the formation and growth of lateral roots (rhizogenesis) fully ensures the main functions of the root - the absorption of water and minerals and fixation in the substrate.

The results of the study of the influence of selective light on the processes of rhizogenesis in seedlings of LDP pea varieties Metsenat showed that the irradiation of the RL does not significantly affect the development and growth of lateral roots (Table 2).

Irradiation of the GL stimulates the process of branching - increases the number and length of lateral roots. Under the action of BL inhibits the formation of lateral roots, but increases their length compared to the control version (Table 2).

The results of the study of the process of rhizogenesis in SDP seedlings of soybean variety Korsak for irradiation with selective light showed that under the action of emergency the number of lateral roots increased, and when irradiated GL and BL - on the contrary the process of rhizogenesis slowed down - the number of lateral roots decreased compared to control (Table 2). The length of lateral roots in soybean SDP seedlings was very small - within $1 \mathrm{~cm}$. A significant effect on their length was detected only

${ }^{20}$ Красільнікова Л.О., Авксентьєва О.О., Садовніченко Ю.О. Анатомія рослин: рослинна клітина, тканини, вегетативні органи. Харків : ХНУ імені В.Н. Каразіна, 2013. $260 \mathrm{c}$.

${ }_{21}$ Творогова В.Е., Осипова М.А., Додуева И.Е., Лутова Л.А. Взаимодействие транскриптационных факторов и фитогормонов в регуляции активности меристем у растений. Экологическая генетика. 2012. № 3. С. 28-40. 
by the action of the green light, irradiation of the red light and blue light did not affect the growth of lateral roots (Table 2).

Table 2

Influence of selective light on rhizogenesis in seedlings of plants with contrast PhPR

\begin{tabular}{|c|c|c|}
\hline Variant & Number of lateral roots, pcs. & Length of lateral roots, $\mathrm{cm}$ \\
\hline & \multicolumn{3}{|c|}{ Long-day plant $($ LDP $)$ of pea Metsenat variety } \\
\hline Control & $10,71 \pm 0,41$ & $3,06 \pm 0,10$ \\
\hline RL $(660 \mathrm{~nm})$ & $10,95 \pm 0,42$ & $3,30 \pm 0,11$ \\
\hline GL $(530 \mathrm{~nm})$ & $11,38 \pm 0,31^{*}$ & $3,62 \pm 0,16^{*}$ \\
\hline BL $(450 \mathrm{~nm})$ & $10,33 \pm 0,14^{*}$ & $3,43 \pm 0,25^{*}$ \\
\hline \multicolumn{3}{|c|}{ Short-day plant $($ SDP $)$ of soybean Corsak variety } \\
\hline Control & $4,1 \pm 0,21$ & $1,1 \pm 0,03$ \\
\hline RL $(660 \mathrm{~nm})$ & $5,0 \pm 0,71^{*}$ & $1,0 \pm 0,07$ \\
\hline GL $(530 \mathrm{~nm})$ & $2,7 \pm 0,35^{*}$ & $1,3 \pm 0,04^{*}$ \\
\hline BL $(450 \mathrm{~nm})$ & $3,3 \pm 0,21^{*}$ & $1,0 \pm 0,07$ \\
\hline Photoperiodically neutral plant $($ PhNP) of soybean Diadema Podillia variety \\
\hline Control & $4,0 \pm 0,20$ & $0,6 \pm 0,04$ \\
\hline RL $(660 \mathrm{~nm})$ & $1,0 \pm 0,05^{*}$ & $1,0 \pm 0,03^{*}$ \\
\hline GL $(530 \mathrm{~nm})$ & $2,7 \pm 0,12^{*}$ & $1,1 \pm 0,06^{*}$ \\
\hline BL $(450 \mathrm{~nm})$ & $2,1 \pm 0,14^{*}$ & $1,0 \pm 0,01^{*}$ \\
\hline
\end{tabular}

*) note - the difference with the control is significant for $p \leq 0,05$

The results of the study of morphogenetic development of the root system in PhNP soybean cultivar Diadema Podillia under the influence of selective light showed that irradiation of the RL, GL and BL significantly inhibits the processes of branching of the main root (Table 2). At the same time, it was found that irradiation with selective light stimulates the growth of lateral roots in length, probably the growth of "elongation".

Thus, research has shown that the process of rhizogenesis - branching of the main root in the LDP is stimulated by the action of the GL, in the SDP by the action of the RL, in PhNP irradiation with selective light inhibits branching - the formation of lateral roots (Fig. 3). 


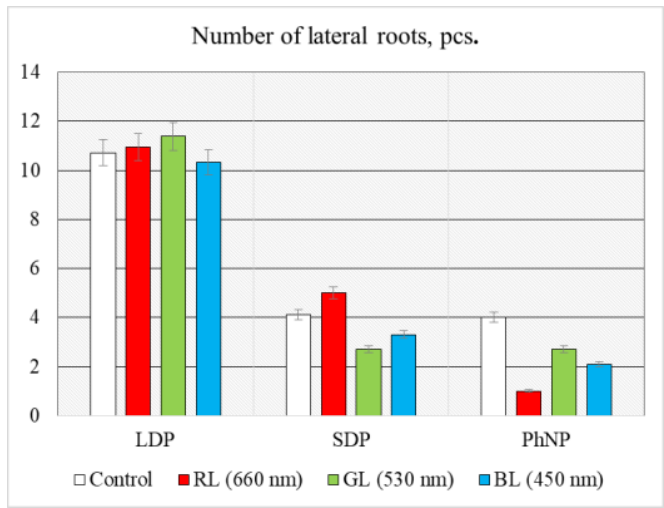

Fig. 3. Influence of selective light on morphogenetic development of the root system (rhizogenesis) in seedlings with contrast PhPR

\section{Growth of root hairs under the action of selective light}

The hair layer is the covering tissue of the root in the absorption zone above the point of growth. It is called the rhizoderm, or epiblem. The cells of this layer form outgrowths - root hairs. They are alive, with thin cellulose shells, parietal layer of cytoplasm and a large central vacuole. The nucleus is located in the part of the cytoplasm that is in the hair, there also penetrates the vacuole. In certain species of plants, each cell of the rhizoderm forms hairs, in others the rhizoderm contains cells of two types - trichoblasts, which form hairs, and atrichoblasts, which do not have them. And in the roots of different plants hairs are formed differently. First, they can be formed by lengthening the entire rhizodermal cell, secondly, the protrusion of the middle part of the outer wall, and thirdly - the protrusion of areas in its lower part. The formation of hairs begins with the appearance on the outer wall of the trichoblast of a small tubercle that grows at the apex and is extended. Root hairs are in close contact with soil particles and absorb water from them osmotically and minerals through active and passive transport mechanisms. The shells of the root hairs slip. This promotes their bonding with soil particles and the absorption of water and substances. Root hairs affect the soil, releasing carbonic, formic or acetic acids, which help dissolve some sparingly soluble mineral salts ${ }^{22}$. The length of the root hairs is $0.1-1$ $\mathrm{mm}$, the density is several hundred per $1 \mathrm{~mm}^{2}$ of the root surface. The hairs do not function for long, a few days: they are destroyed in contact with solid

22 Бобровницкий Ю. Образование разветвленных корневых волосков у Arabidopsis thaliana при прогрессирующей засухе. Цитология и генетика. 2016. T. 50. № 5. C. 72-78. DOI: 10.3103/S0095452716050030. 
soil particles and die, to replace them above the point of growth, new ones are formed.

Regulation of the development of root hairs, including their branching, can be carried out by affecting the cytoskeleton - the apparatus of microtubules. It is known that microtubules are involved in regulating the direction and stability of apical growth of root hairs. It was previously found that depolymerization or stabilization of microtubules in root hair cells leads to a violation of the polarity of their growth and causes the formation of multiple independent growth points in one root hair ${ }^{23}$.

The study of the influence of selective light on the development of root hairs in seedlings of LDP pea varieties Metsenat showed that the irradiation of selective light of the RL, GL and BL reduces the area of the suction zone. The maximum reduction - almost twice occurs during irradiation of the RL (Table 3.).

Table 3

The effect of selective light on the development of root hairs in seedlings of plants with contrast PhPR

\begin{tabular}{|c|c|c|}
\hline Variant & Area of maturation zone, $\mathrm{mm}^{2}$ & \% of control \\
\hline \multicolumn{3}{|c|}{ Long-day plant (LDP) of pea Metsenat variety } \\
\hline Control & $17 \pm 0,09$ & 100 \\
\hline RL $(660 \mathrm{~nm})$ & $9 \pm 0,05^{*}$ & 53 \\
\hline GL $(530 \mathrm{~nm})$ & $14 \pm 0,07^{*}$ & 82 \\
\hline BL $(450 \mathrm{~nm})$ & $14 \pm 0,05^{*}$ & 82 \\
\hline \multicolumn{2}{|c|}{ Short-day plant $($ SDP $)$ of soybean Corsak variety } \\
\hline Control & $6 \pm 0,01$ & 100 \\
\hline RL $(660 \mathrm{~nm})$ & $10 \pm 0,01^{*}$ & 167 \\
\hline GL $(530 \mathrm{~nm})$ & $9 \pm 0,02^{*}$ & 150 \\
\hline BL $(450 \mathrm{~nm})$ & $10 \pm 0,01^{*}$ & 167 \\
\hline Photoperiodically neutral plant $(P h N P)$ of soybean Diadema Podillia variety \\
\hline Control & $5 \pm 0,01$ & 100 \\
\hline RL $(660 \mathrm{~nm})$ & $12 \pm 0,02^{*}$ & 240 \\
\hline GL $(530 \mathrm{~nm})$ & $10 \pm 0,03^{*}$ & 200 \\
\hline BL $(450 \mathrm{~nm})$ & $9 \pm 0,01^{*}$ & 180 \\
\hline
\end{tabular}

*) note - the difference with the control is significant for $p \leq 0,05$

The results of the study of the effect of irradiation on the growth of root hairs in SDP and PhNP of soybean showed the opposite relationship in comparison with the seedlings of pea LDP. In experimental soybean seedlings - by irradiation with selective light of the RL, GL and BL

\footnotetext{
${ }^{23}$ Влияние окадаиновой кислоты на морфологию корня Arabidopsis thaliana и организацию микротрубочек в его клетках / Я.А. Шеремет и др. Цитология $u$ генетика. 2009. № 1. С. 3-10.
} 
significant stimulation of root hair growth - an increase in the area of the suction zone (Table 3, Fig. 4), which coincides with the literature obtained in experiments with the model plant Arabidopsis thaliana ${ }^{24}$.

The main function of the root, as already mentioned, is the absorption of minerals and water from the soil, which can be realized by stimulating rhizogenesis - branching of roots or by increasing the suction zone (perhaps these reactions are realized at different stages of growth).

Thus, in the course of the conducted research the opposite reaction of root hairs development to the action of selective light irradiation of all spectra of RL, GL and BL in seedlings with contrast photoperiodic reaction - pea LDP and SDP and PhNP of soybean. Earlier, we showed the opposite reaction to irradiation of the LDP of pea of Metsenat variety and SDP of Korsak variety for proliferative activity of root meristems of seedlings ${ }^{25}$.

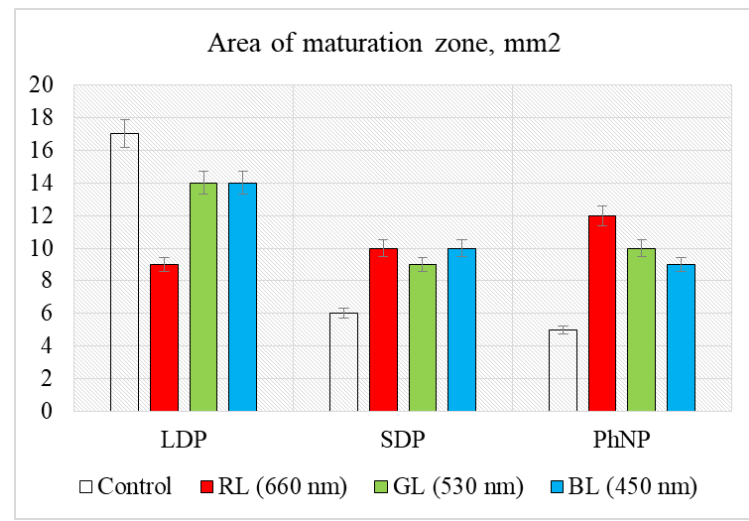

Fig. 4 The effect of selective light on the development of root hairs in seedlings with contrast PhPR

\section{CONCLUSIONS}

The obtained experimental results allow us to formulate the following conclusions:

${ }^{24}$ Хаблак С.Г. Влияние мутаций по генам восприятия и передачи светового сигнала на строение корневых волосков Arabidopsis thaliana (L.) Heynh. Beстник Томского государственного университета. Биология. 2013. № 3(23). С. 127-136.

25 Авксентьєва О.О, Батуєва Є.Д. Вплив червоного світла (660 нм) на проліферативну активність та ростові реакції у проростків рослин із контрастною фотоперіодичною реакцією. Вісник Харківського національного університету імені В.Н. Каразіна. Серія «Біологія». 2020. № 34. C. 120-130. DOI: 10.26565/2075-54572020-34-16. 
1. Irradiation with monochromatic light affects the development of the root system in the studied seedlings of legumes with a contrasting photoperiodic reaction - inhibits the linear growth of the main root, but stimulates the accumulation of biomass of the root system.

2. The process of rhizogenesis - the formation of lateral roots under the action of selective light is characterized by inhibition of branching, but at the same time stimulating the linear growth of lateral roots.

3. Irradiation of RL (660 nm), BL (450nm), GL (530 nm) significantly inhibits the formation of root hairs in seedlings of LDP peas, but significantly stimulates this process in seedlings SDP and PhNP soybean.

4. The greatest morphogenetic effect on the development of the root system in seedlings of LDP was detected by irradiation of the GL $(530 \mathrm{~nm})$, in seedlings of SDP - by the influence of RL $(660 \mathrm{~nm})$.

5. Since seedlings of plants with contrast PhPR - LDP of pea variety Metsenat and SDP of soybean variety Korsak show opposite effects on the action of selective light irradiation, it suggests that a genetically determined trait - photoperiodic response of plants - determines the leading role of a particular photoreceptor in the system of light signal perception and the formation of the morphogenetic response of the root system.

\section{SUMMARY}

The work is devoted to the analysis of photomorphogenetic processes of the root system of seedlings of legume plants by activation of photoreceptor systems by selective light of different spectrum of RL $(660 \mathrm{~nm})$, GL $(530 \mathrm{~nm})$ and BL $(450 \mathrm{~nm})$. It is shown that seedlings of LDP of pea the most responsive to radiation $(530 \mathrm{~nm})$ - apical growth of the main root is activated, the processes of rhizogenesis - the number and growth of lateral roots, but inhibits the development of root hairs. In seedlings of SDP and PhNP soybean culture, the maximum response to the studied processes was detected under the influence of RL $(660 \mathrm{~nm})$. It is assumed that a genetically determined trait - the photoperiodic reaction of plants - determines the leading role of a particular photoreceptor in the system of light signal perception and the formation of the morphogenetic response of the root system.

\section{REFERENCES}

1. Молекулярно-генетические и гормональные механизмы ветвления корневых систем / Е.Л. Ильина и др. Сельскохозяйственная биология. 2017. Том 52. № 5. С. 856-868. DOI: 10.15389/agrobiology.2017.5.856rus.

2. Войцеховская О.В. Фитохромы и другие (фото)рецепторы информации у растений. Физиология растений. 2019. Т. 66. № 3. C. 163-177. DOI: 10.1134/S0015330319030151. 
3. Головацкая И.Ф. Морфогенез растений и его регуляция : учебное пособие. Томск : ТГУ, 2016. $171 \mathrm{c.}$

4. Синещеков В.А. Фитохром А: полиморфизм и функциональность. Москва : Научный мир, 2013. 162 с.

5. Franklin K.A., Quail P.H. Phytochrome functions in Arabidopsis Development. J. Exp. Botany. 2010. V. 61. P. 11-24. DOI: $10.1093 / \mathrm{jxb} / \mathrm{erp} 304$.

6. Федоренко О.М., Савушкин А.И. Генетические аспекты фитохромной регуляции процессов фотоморфогенеза у высших растений. Успехи современной биологии. 2006. Т. 126. № 2. С. 201-212.

7. Franklin K.A., Whitelam G.C. The signal transducing photoreceptors of plants. Int. J. Dev. Biol. 2005. V. 49. P. 653-664. DOI: $10.1387 / \mathrm{ijdb} .051989 \mathrm{kf}$.

8. Root-localized phytochrome chromophore synthesis is required for photoregulation of root elongation and impacts root sensitivity to jasmonic acid in Arabidopsis / S.E. Costigan et al. Plant Physiol. 2011. V. 157. P. 1138-1150. DOI: 10.1104 / стр.111.184689.

9. Кулаева О.Н. Как свет регулирует жизнь растений. Соросовский образовательный журнал. 2001. № 7. С. 6-12.

10. Генетична детермінація та функція RR-білків - регуляторів фотоперіодичних реакцій і циркадних ритмів у рослин / В.М. Тоцький та ін. Цитология и генетика. 2012. Т. 46. № 5. С. 72-91. DOI: $10.3103 /$ S009545271205009X.

11. Головацкая И.Ф., Карначук Р.А. Роль зеленого света в жизнедеятельности растений. Физиология растений. 2015. Т. 62. № 6. C. 776-791. DOI: 10.7868/80015330315060081.

12. Casal J.J. Photoreceptor signaling networks in plant response to shade Апnи. Rev. Plant Biol. 2013. V. 64. P. 403-427. DOI: 10.1146/annurev-arplant-050312-120221.

13. Plant flavoprotein photoreceptors / J.M. Christie et al. Plant Cell Physiol. 2015 Mar;56(3):401-13. DOI: 10.1093/pcp/pcu196.

14. Light-regulation plant growth and development / C. Kami et al. Curr. Top. Dev. Biol. 2010. V. 91. P. 29-66. DOI: 10.1016/S0070-2153(10)91002-8.

15. Weller J.L., Ortega R. Genetic control of flowering time in legumes Front. Plant Sci., 2015. DOI: https://doi.org/10.3389/fpls.2015.00207.

16. Molecular Dissection of the Roles of Phytochrome in Photoperiodic Flowering in Rice / A. Osugi et al. Plant Physiol. 2011. V. 157. P. 1128-1137. DOI: https://doi.org/10.1104/pp.111.181792.

17. Эверт В.Ф. Анатомия растений Эзау. Меристемы, клетки и ткани растений: строение, функции и развитие. Москва : БИНОМ, 2016. 600 с.

18. Иванов В.Б. Клеточные механизмы роста растений. Москва : Наука, 2011. 104 с. 
19. Alarcón M. Victoria, Salguero Julio and Lloret Pedro G. Auxin Modulated Initiation of Lateral Roots Is Linked to Pericycle Cell Length in Maize Front. Plant Sci. 2019. URL: https://doi.org/10.3389/fpls.2019.00011.

20. Красільнікова Л.О., Авксентьєва О.О., Садовніченко Ю.О. Анатомія рослин: рослинна клітина, тканини, вегетативні органи. Харків : ХНУ імені В.Н. Каразіна, 2013. 260 с.

21. Взаимодействие транскриптационных факторов и фитогормонов в регуляции активности меристем у растений / В.Е. Творогова и др. Экологическая генетика. 2012. № 3. С. 28-40.

22. Бобровницкий Ю. Образование разветвленных корневых волосков у Arabidopsis thaliana при прогрессирующей засухе. Цитология и генетика. 2016. Т. 50. № 5. С. 72-78. DOI: $10.3103 / \mathrm{S} 0095452716050030$.

23. Влияние окадаиновой кислоты на морфологию корня Arabidopsis thaliana и организацию микротрубочек в его клетках / Я.А. Шеремет и др. Цитология и генетика. 2009. № 1. С. 3-10.

24. Хаблак С.Г. Влияние мутаций по генам восприятия и передачи светового сигнала на строение корневых волосков Arabidopsis thaliana (L.) Hеynh. Вестник Томского государственного университета. Биология. 2013. № 3(23). С. 127-136.

25. Авксентьєва О.О, Батуєва Є.Д. Вплив червоного світла (660 нм) на проліферативну активність та ростові реакції у проростків рослин 3 контрастною фотоперіодичною реакцією. Вісник Харківського національного університету імені В.Н. Каразіна. Серія «Біологія». 2020. № 34. C. 120-130. DOI: 10.26565/2075-5457-2020-34-16.

\section{Information about authors:} Avksentieva O. O.,

Candidate of Biological Sciences, Associate Professor, Associate Professor at the Department of Plant and Microorganisms

Physiology and Biochemistry

V. N. Karazin Kharkiv National University 4, Svobody square, Kharkiv, 61022, Ukraine

Batuyeva Ye. D., Graduate Student at the Department of Plant and Microorganisms Physiology and Biochemistry V. N. Karazin Kharkiv National University 4, Svobody square, Kharkiv, 61022, Ukraine 